\title{
EXPRESSION OF SEC61 $\alpha$ IN F9 AND P19 TERATOCARCINOMA CELLS AFTER RETINOIC ACID TREATMENT
}

\author{
FERREIRA, L. R., ${ }^{1}$ VELANO, C. E. E., ${ }^{2}$ BRAGA, E. C., ${ }^{2}$ PAULA, C. C., ${ }^{2}$ \\ MARTÉLLI-JUNIOR, H. ${ }^{3}$ and SAUK, J. J. ${ }^{4}$ \\ 'Departamento de Ciências Morfológicas, Grupo de Pesquisa de Biomedicina, \\ Pontifícia Universidade Católica, PUC-Minas, Poços de Caldas, MG, Brazil \\ ${ }^{2}$ Faculdade de Ciências Médicas, Universidade de Alfenas, MG, Brazil \\ ${ }^{3}$ Faculdade de Odontologia, Unimontes, Montes Claros, MG, Brazil \\ ${ }^{4}$ Dept. of Oral Pathology, Dental School, University of Maryland, Baltimore, MD, USA \\ Correspondence to: Luciano Resende Ferreira, Rua Comandante Ary Lopes Buono, 177, \\ Poços de Caldas, MG, Brazil, e-mail: resende @ pucpcaldas.br \\ Received September 4, 2002 - Accepted October 2, 2002 - Distributed May 31, 2003
}

(With 5 figures)

\begin{abstract}
Nascent procollagen peptides and other secretory proteins are transported across the endoplasmic reticulum (RE) membrane through a protein-conducting channel called the translocon. Sec61 $\alpha$, a multispanning membrane translocon protein, has been implicated as essential for translocation of polypeptides chains into the cisterns of the ER. However, it is not known whether Sec61 $\alpha$ is ubiquitously expressed in collagen producing teratocarcinoma cells. Furthermore, the production, expression, and utilization of Sec61 $\alpha$ may depend on the cell differentiation stage. Stem cells from many cultured teratocarcinoma cell lines such as F9 and P19 cells are capable of differentiation in response to low retinoic acid concentrations. This differentiation of the tumorigenic stem cells results in tumorigenicity loss. For this study, mouse F9 and P19 teratocarcinoma cells were grown in culture medium treated with or without retinoic acid. Expression of Sec61 $\alpha$ was determined by reverse trancriptase polimerase chain reaction (RT-PCR). In untreated conditions, F9 cells expressed undetected Sec61 $\alpha$ amounts. It was also demonstrated that Sec61 $\alpha$ expression is stimulated in F9 cells after retinoic acid treatment for 72 hours. No changes were found in Sec61 $\alpha$ expression in P19 cells after retinoic acid treatment. These data indicate that the expression of Sec61 $\alpha$ is enhanced with retinoic acid induced differentiation of F9 teratocarcinoma cells.
\end{abstract}

Key words: Sec61 $\alpha$, expression, F9 teratocarcinoma cells, retinoic acid.

\section{RESUMO}

\section{Expressão gênica de Sec61 $\alpha$ após tratamento com ácido retinóico em células de teratocarcinoma F9 e P19}

Peptídeos nascentes de pró-colágeno e outras proteínas são transportadas por intermédio da membrana do retículo endoplasmático por um canal de transporte de proteínas chamado de tanslocon. Sec61 $\alpha$, uma proteína transmembrânica do translocon, tem sido apontada como essencial para translocação de cadeias nascentes de polipeptídeos para as cisternas do retículo endoplasmático. Entretanto, não se sabe se Sec61 $\alpha$ é constitutivamente expressa em células de teratocarcinoma produtoras de colágeno. Além disso, a expressão e a utilização de Sec61 $\alpha$ podem ser dependentes do estágio de diferenciação celular. Células progenitoras pluripotentes obtidas de muitas linhagens de células de teratocarcinoma, incluindo, por exemplo, células 
F9 e P19, são capazes de diferenciação em resposta a baixas concentrações de ácido retinóico. Essa diferenciação de células tumorais causa perda de sua carcinogenicidade. Para este estudo, células de teratocarcinoma F9 e P19 de camundongos foram cultivadas em meios de cultura tratados com ou sem ácido retinóico. A expressão de Sec61 $\alpha$ foi determinada pelo método de "reverse transcriptase-polymerase chain reaction" (RT-PCR). Em condições não tratadas, células F9 expressaram quantidades não detectáveis de Sec61 $\alpha$. De forma similar, experimentos de RT-PCR demonstraram que a expressão gênica de Sec61 $\alpha$ é estimulada nas células F9 após tratamento com ácido retinóico por 72 horas. Não foram detectadas diferenças na expressão de Sec61 $\alpha$ nas células P19 após tratamento com ácido retinóico. Esses dados demonstram que a expressão de Sec61 $\alpha$ é aumentada em células de teratocarcinoma F9 após diferenciação com ácido retinóico.

Palavras-chave: Sec61 $\alpha$, expressão gênica, células de teratocarcinoma F9, ácido retinóico.

\section{INTRODUCTION}

Retinoic acid (RA) is a natural acidic derivative of vitamin A (retinol), which can affect proliferation and differentiation of a variety of cell types, and pattern formation during development (Strickland \& Mahdavi, 1978; DeLuca, 1992). Retinoic acid can mimic the action of the polarizing zone activity in the developing chick limb (Tickle et al., 1982, 1985), and cause specific alterations in the proximal-distal pattern of regenerating amphibian limbs (Tickle et al., 1985). In addition, retinoic acid can suppress the process of carcinogenesis in vivo (Moon \& Metha 1990; Shklar et al., 1980) and inhibit the development of the transformed phenotype in vitro (LaRosa \& Gudas, 1988).

Studies in experimental animals have demonstrated that retinoids suppress carcinogenesis in a variety of epithelial tissues, including skin, trachea, lung, and oral mucosa (Moon \& Metha, 1990; Shklar et al., 1980). Clinical studies have demonstrated the efficacy of retinoids in suppressing oral premalignant lesions, second primary carcinomas in patients with head and neck or lung cancer, and also skin cancers in patients with xeroderma pigmentosum (Hong et al., 1986; Kraemer et al., 1988; Smith et al., 1992; Kikugawa et al., 2000; Wan et al., 2001). In tissue culture systems, RA induces differentiation of murine F9 teratocarcinoma cells (Boylan \& Gudas, 1991; Fischer et al., 2000; Wakabayashi et al., 2000; Kubota et al., 2001) and can also influence differentiation of HL-60 human promyelocytic leukemia cells (Brietman et al., 1980; Treigyte et al., 2000; Hussain et al., 2000), melanoma cells (Lotan \& Lotan, 1980) and human neuroblastoma cells (Haussler et al., 1983).

The F9 cells comprise a cultured cell line derived from a mouse testicular teratocarcinoma
(Strickland \& Mahdavi, 1978). The F9 murine teratocarcinoma stem cells resemble the pluripotent inner cell mass cells of mouse blastocysts. Thus, F9 cells provide an important model system with which to study critical early events in mouse development (Strickland \& Mahdavi, 1978; Fischer et al., 2000; Kubota et al., 2001). These embryonal carcinoma cells, which undergo very limited differentiation under normal culture conditions, can be induced to differentiate into parietal endodermal cells (primitive endoderm-like cells) in the presence of retinoic acid and dibutyryl cAMP (Strickland et al., 1980; Kubota et al., 2001). The P19 cells are a euploid (40:XY) teratocarcinoma cell line derived from an embryonal carcinoma induced in a $\mathrm{C} 3 \mathrm{H} / \mathrm{He}$ strain mouse (Wakabayashi et al., 2000). These pluripotent cells, which differentiate poorly under normal culture conditions, can be induced to differentiate into neuronal, glial, or fibroblast-like cells in the presence of retinoic acid (Wakabayashi et al., 2000; FernandezRachubinski et al., 2001).

Secretory proteins produced by teratocarcinoma cells are transported across the endoplasmic reticulum (ER) membrane through a protein-conducting channel. This channel is comprised of ER associated proteins called translocon, which includes the Sec61 $\alpha$ complex (Simon \& Blobel, 1991; Kellaris et al., 1991; Rapoport et al., 1999). Sec61 $\alpha$ is a multispanning membrane protein and the largest component of the Sec61p complex. This protein is considered essential for translocation of polypeptide chains through this channel into the ER cisterns of the ER (Gorlich et al., 1992; Greenfield \& High, 1999). Sec61 $\alpha$ expression may depend on the cell differentiation stage. However, it is not known whether Sec61 $\alpha$ is ubiquitously expressed in collagen-producing cells, and under stress conditions such as heat shock. 
Stem cells from many cultured teratocarcinoma cell lines, such as mouse F9 and P19 cells, are capable of differentiation in response to low retinoic acid concentrations (Wang \& Gudas, 1990; Boylan \& Gudas, 1991). This tumorigenic stem cell differentiation results in the loss of tumorigenicity (Jetten et al., 1992; Lotan, 1993). Therefore, teratocarcinoma cell lines provide a model with which to examine the association between the process of cell differentiation and Sec61 $\alpha$ expression. This study aimed to investigate the expression of Sec61 $\alpha$ in F9 and P19 cells following retinoic acid and heat shock treatment.

\section{MATERIAL AND METHODS}

\section{F9 teratocarcinoma cells}

The F9 teratocarcinoma cells were obtained from the American Type Tissue Collection and grown to confluence in $75 \mathrm{~cm}^{2}$ plastic flasks using Dulbecco's modified Eagle's medium, 10\% FBS, 1.16 g/liter glutamine, and $100 \mathrm{mg} / \mathrm{ml}$ streptomycin at $37^{\circ} \mathrm{C}$ in $5 \% \mathrm{CO}_{2}$. The $\mathrm{F} 9$ stem cells $\left(1 \times 10^{5}\right.$ cells $)$ were plated on gelatinized tissue culture plates containing $10 \mathrm{ml}$ of medium, and induced to differentiate into parietal endoderm cells after treatment with all-trans retinoic acid $\left(10^{-6} \mathrm{M}\right)$ for 4 days. Retinoic acid was added $24 \mathrm{~h}$ after plating. All trans RA (Sigma, St. Louis, MO, USA) stock solution was dissolved in $100 \%$ ethanol and stored in the dark. The controls were treated with vehicle alone (ethanol) and processed in parallel with the experimental groups. The cells were grown under normal conditions $\left(37^{\circ} \mathrm{C}\right)$ or at $43^{\circ} \mathrm{C}$ (heat shock) for $90 \mathrm{~min}$.

\section{P19 teratocarcinoma cells}

Mouse P19 teratocarcinoma cell lines were obtained from the American Type Tissue Collection and grown to confluence in $75 \mathrm{~cm}^{2}$ plastic flasks using Alpha modified Eagle's medium, 10\% FBS, $1.16 \mathrm{~g} /$ liter glutamine, and $100 \mathrm{mg} / \mathrm{ml}$ streptomycin at $37^{\circ} \mathrm{C}$ in $5 \% \mathrm{CO}_{2}$. These $\mathrm{P} 19$ cells were induced to differentiate into fibroblast-like cells after treatment with all-trans retinoic acid $\left(10^{-6} \mathrm{M}\right)$ for 4 days as described above for F9 cells.

\section{MDCK cells}

The MDCK (Madin-Darby canine kidney) cell line was derived from a kidney of an apparently normal adult female cocker spaniel. The line was established in a medium consisting of $0.5 \%$ lactalbumin hydrolysate in 95\% Earle's BSS (balanced salt solution) and $5 \%$ bovine serum. The initial cells appeared to be fibroblast-like, and were removed from the culture six times at approximately 7 day intervals. MDCK cell lines were obtained from the American Type Tissue Collection and grown to confluence in $75 \mathrm{~cm}^{2}$ plastic flasks using Eagle's modified essential medium with Earle's BSS, 10\% FBS, 1.16 g/liter glutamine, and $100 \mathrm{mg} / \mathrm{ml}$ streptomycin at $37^{\circ} \mathrm{C}$. The MDCK cells were grown to confluence, frozen, and recovered for the experiments. Cells between the third and fourth passage were utilized for the experiments. These cells were used in this study as the control.

\section{RNA extraction}

The RNA was extracted from F9, P19, and MDCK cells using standard procedures (Wang \& Gudas, 1990). The cells were collected by centrifugation at $300 \mathrm{xg}$ for $5 \mathrm{~min}$ at $4^{\circ} \mathrm{C}$ and washed in ice-cold PBS. Fifteen $\mathrm{ml}$ of prechilled denaturing solution (40\% guanidine thiocyanate in CSB buffer, Promega, Madison, WI) was then added to the cells. The samples were then disrupted with a high speed homogenizer (Brinkmann Polytron, New Haven, CT) for 30 seconds. After homogenization, $1.2 \mathrm{ml}$ of $2 \mathrm{M}$ sodium acetate, $\mathrm{pH} 4.0$, was added to the samples. The samples were extracted with $12 \mathrm{ml}$ of $1: 1: 1$ phenol/chloroform/isoamyl alcohol mixture (Sigma Co.). The samples were transferred to a $50 \mathrm{ml}$ thickwalled polypropylene tube (DEPC, diethylpyrocarbonate-treated) and centrifuged at $10,000 \mathrm{x}$ $\mathrm{g}$ for $20 \mathrm{~min}$ at $4^{\circ} \mathrm{C}$. The top aqueous phase which contains the RNA was removed and transferred to a fresh DEPC-treated tube. The RNA was precipitated from the aqueous phase by adding an equal amount of isopropanol to each sample and incubating overnight at $-20^{\circ} \mathrm{C}$. The RNA pellet was collected by centrifugation at $10,000 \times \mathrm{g}$ for $15 \mathrm{~min}$ at $4^{\circ} \mathrm{C}$, resuspended in RNase-free water, and stored at $-20^{\circ} \mathrm{C}$. The RNA was resuspended in nuclease-free water, and RNA concentrations were determined by spectrophotometry at $260 \mathrm{~nm}$. The RNA integrity was verified by visualization of sized-resolved RNA on ethidium bromide stained $1 \%$ agarose gels. The RNA yields ranged from 0.2 to $71 \mu \mathrm{g} / \mu \mathrm{l}$.

\section{PCR amplifications}

One to $5 \mu \mathrm{g}$ of extracted RNA was resuspended in $13 \mu \mathrm{l}$ of DEPC-treated water. One $\mu 1$ of Oligo$\mathrm{dT}(10 \mu \mathrm{M})$ was added to each sample. The samples were immediately heated to $70^{\circ} \mathrm{C}$ for $10 \mathrm{~min}$ and quenched on ice for $1 \mathrm{~min}$. The following solutions 
were immediately added to the samples: $2 \mu \mathrm{l}$ of $10 \mathrm{X}$ synthesis buffer (200 mM Tris-HCl, pH 8.4, $500 \mathrm{mM}$ $\mathrm{KCl}, 20 \mathrm{mM} \mathrm{MgCl}$ ), $1 \mu \mathrm{l}$ of $10 \mathrm{mM}$ dNTP mix, 2 $\mu \mathrm{l}$ of $0.1 \mathrm{M}$ of DTT, and $1 \mu \mathrm{l}$ of $200 \mathrm{U} / \mu \mathrm{l}$ SuperScript II RT (BRL Inc.). The samples were incubated for $10 \mathrm{~min}$ at room temperature, transferred to $42^{\circ} \mathrm{C}$, and incubated for an additional $50 \mathrm{~min}$. Reverse transcription was terminated by placing the samples at $70^{\circ} \mathrm{C}$ for $15 \mathrm{~min}$. To each sample was added RNaseH $(1 \mu \mathrm{l})$, and the samples were incubated for $20 \mathrm{~min}$ at $37^{\circ} \mathrm{C}$. The following solutions were then added to each sample: $8 \mu$ of $10 \mathrm{X}$ synthesis buffer, $1 \mu \mathrm{l}$ of upstream primer $(10 \mu \mathrm{M})$, and $1 \mathrm{ml}$ of downstream primer $(10 \mu \mathrm{M})$. Primers were designed for homologous regions of rat and canine Sec61 $\alpha$ (Gorlich et al., 1992). Upstream primer sequence was 5'-GAACTTCTG CAAAAAGGGTACGG-3' (23mer); the downstream primer sequence was 5'TTCTACACTTCCAACAT CCCC-3' (21mer). The expected size of the amplified product was 410 base pairs (bp) (Gorlich et al., 1992). Following the addition of the primers, a wax pellet was added to each tube, and the tubes were incubated at $80^{\circ} \mathrm{C}$ for $7 \mathrm{~min}$. The wax was allowed to harden, and $1 \mu \mathrm{l}$ of Taq DNA polymerase (Promega Corp., Madison, Wisc.) and $68 \mu \mathrm{l}$ of sterile distilled water were added on to the top of the wax. Thermal cycling consisted of one cycle of $6 \mathrm{~min}$ at $94^{\circ} \mathrm{C}, 2 \mathrm{~min}$ at $59^{\circ} \mathrm{C}$, and 1 minute at $72^{\circ} \mathrm{C}$, followed by 35 cycles of $1 \mathrm{~min}$ at $94^{\circ} \mathrm{C}, 1 \mathrm{~min}$ at $59^{\circ} \mathrm{C}$, and $1 \mathrm{~min}$ at $72^{\circ} \mathrm{C}$. The PCR products were electrophoresed on $7 \%$ polyacrylamide gels, and products were visualized by ethidium

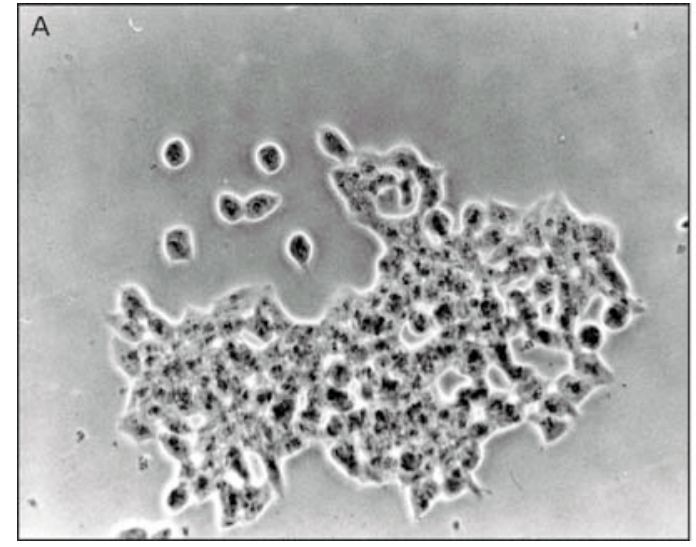

bromide staining and ultraviolet (UV) transillumination of the gel.

\section{RESULTS}

Under normal conditions, the F9 mouse teratocarcinoma stem cell line proliferates spontaneously and normally displays dense compact morphology of cells which tend to aggregate into colonies (Fig. 1A). In response to RA treatment, F9 differentiated from a homogeneous population of primitive endoderm cells into a population of more differentiated parietal endoderm cells (Fig. 1B), showing morphologically a more dispersed configuration and increased number of cellular processes.

In the absence of any treatment, the plated aggregates of P19 cells contained undifferentiated embryonal carcinoma cells that adhered to each other, forming small aggregates. Treatment of P19 cells with all-trans retinoic acid $\left(10^{-6} \mathrm{M}\right)$ for 4 days resulted in differentiation into fibroblastlike cells (results not shown). Treatment of MDCK cells with RA did not alter the fibroblast-like appearance of these cells (Fig. 2A and B).

The RNA extraction and RT-PCR amplification were performed in order to verify the expression of Sec61 $\alpha$ after retinoic acid treatment. Since the primer utilized in this experiment is based on canine Sec61 $\alpha$ cDNA sequence, MDCK cells were used in these experiments as control cells. The cDNA samples from MDCK and F9 cells amplified with both $\operatorname{Sec} 61 \alpha(410$ bp) and $\beta$-actin primers are shown in Fig. 3.

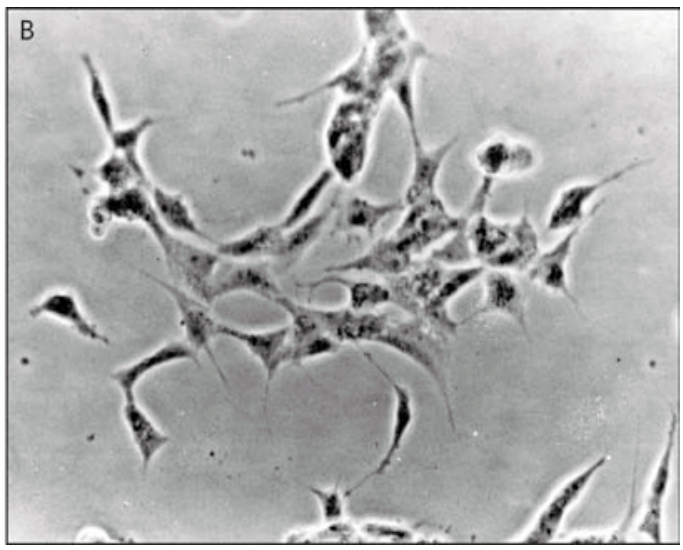

Fig. 1 - (A, B). Phase contrast photomicrographs of F9 teratocarcinoma cells illustrating the variation in morphology after treatment with retinoic acid. Cell aggregates were plated and grown in: A, normal medium (a-medium plus 10\% FBS); and B, in medium containing $10^{-6} \mathrm{M}$ retinoic acid (final magnification $\times 220$ ). 

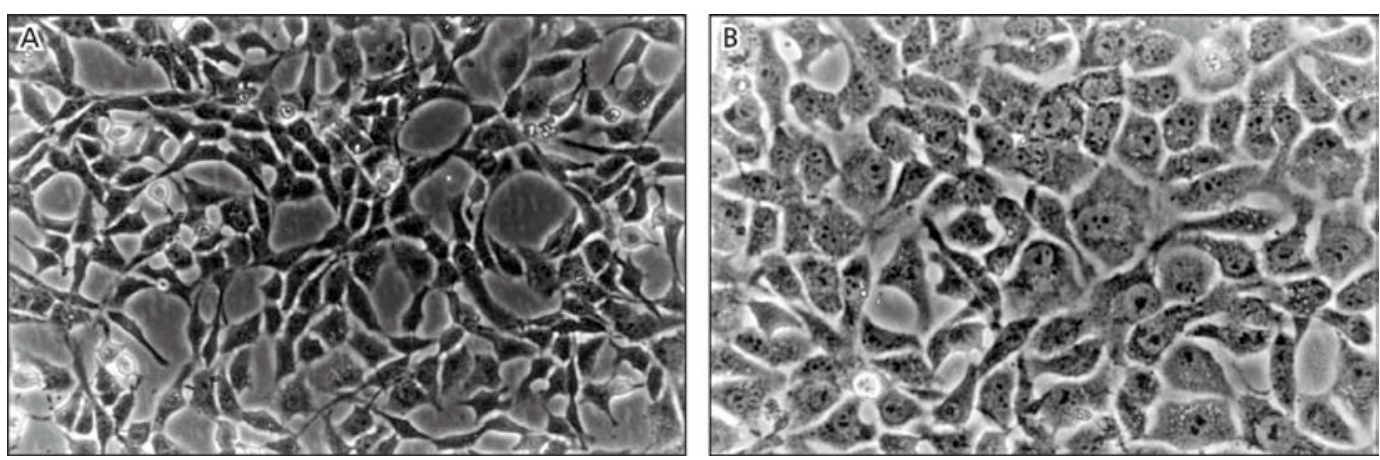

Fig. 2 - (A, B). Monolayer culture of MDCK (Madin-Darby canine kidney) cells showing abundant cytoplasm and a cuboidal appearance. Cell aggregates were plated and grown in: A, normal medium (a-medium plus 10\% FBS) (final magnification $x$ 220); and B, in medium containing $10^{-6} \mathrm{M}$ retinoic acid (final magnification $\times 280$ ).

An amplified product for Sec61 $\alpha$ primer was detected in samples from both control and retinoic acid treated in MDCK cells (Fig. 3, lanes 1 \& 2, respectively). In F9 cells, however, a band of $410 \mathrm{bp}$ (Sec61 $\alpha$ primer) was detected only in samples from retinoic acid treated cells (Fig. 3, lane 4). The next experiment was performed to verify whether Sec61 $\alpha$ expression is altered under different metabolic conditions such as heat-shock treatment (Fig. 4). Following treatment with retinoic acid, an amplified product of appropriate size for Sec61 $\alpha$ primer was present in samples from both control (incubated at $37^{\circ} \mathrm{C}$ ) and heat shocked (incubated at $43^{\circ} \mathrm{C}$ ) cells (Fig. 4, lanes $3 \& 4$, respectively). The amplified product for Sec61 $\alpha$ primer was not detected in samples from cells that were not treated with retinoic acid following heat-shock (Fig. 4, lane 2).

Finally, we investigated whether Sec61 $\alpha$ expression was also altered following retinoic acid treatment in another teratocarcinoma cell line: P19 cells (Fig. 5). The amplified product for Sec61 $\alpha$ primer from $\mathrm{P} 19$ cells was detected in both control and retinoic acid-treated samples (Fig. 5, lanes $1 \& 2$ ).

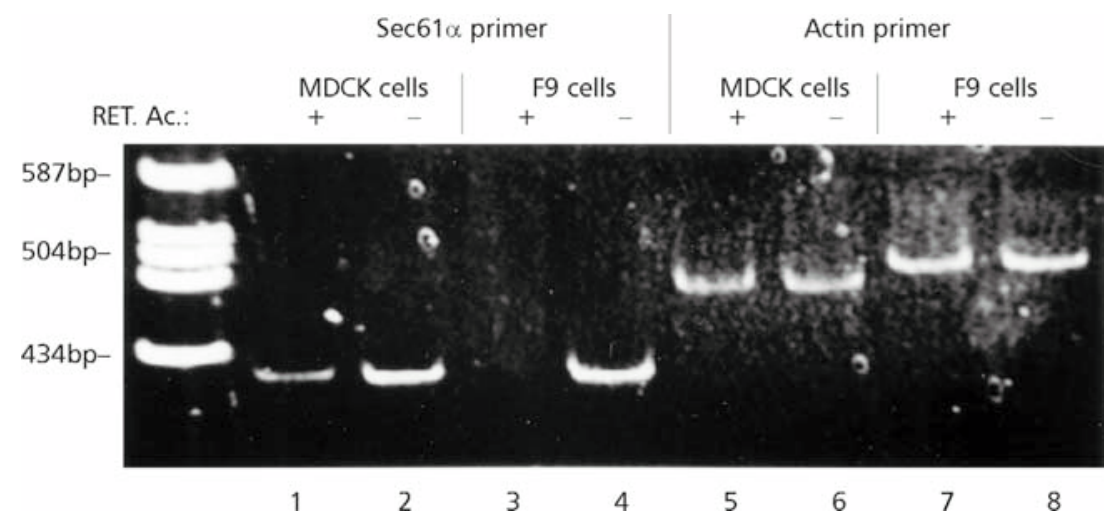

Fig. 3 - Expression of Sec $61 \alpha$ in canine MDCK and mouse F9 cells following retinoic acid treatment. The PCR products from F9 cells untreated (lanes $3 \& 7$ ) and treated (lanes 4 \& 8) with retinoic acid, and from MDCK cells also untreated (lanes $1 \&$ 5 ) and treated (lanes $2 \& 6$ ) were electrophoresed on 7\% polyacrylamide gels. The products amplified by the Sec61 $\alpha$ primers (lanes 1-4) and control actin primers (5-8) were run side-by-side on gels, stained with ethidium bromide, and photographed. The expected size of the amplified product of Sec $61 \alpha$ primer was 410 base pairs on the basis of gel electrophoresis. The expected size of the actin control was 490 base pairs. 


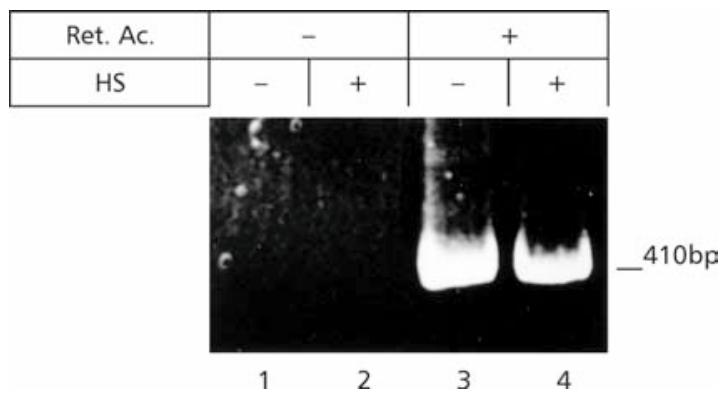

Fig. 4 - Expression of Sec61 $\alpha$ in F9 cells following retinoic acid treatment and heat shock. Prior to RNA extraction, F9 cells were incubated at $37^{\circ} \mathrm{C}$ with (lanes $3 \& 4$ ) or without (lanes $1 \& 2$ ) retinoic acid for 4 days. The cells were then incubated for additional $90 \mathrm{~min}$ at $37^{\circ} \mathrm{C}$ (control cells, Lanes $1 \& 3$ ) or at $43^{\circ} \mathrm{C}$ (heat-shocked cells, lanes $2 \& 4$ ). The PCR products from F9 cells were electrophoresed on $7 \%$ polyacrylamide. The products amplified by the Sec61 $\alpha$ primers treated with retinoic acid and heat-shock were run side-by-side on gels, stained with ethidium bromide, and photographed. The expected size of the amplified product was 410 base pairs on the basis of gel electrophoresis.

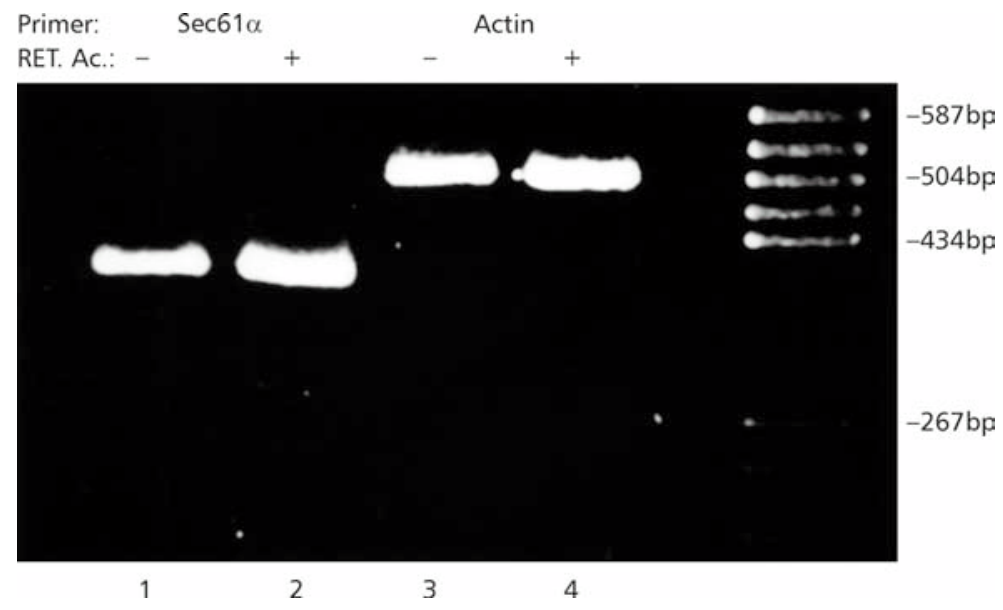

Fig. 5 - Expression of Sec61 $\alpha$ in P19 cells following retinoic acid treatment. Prior to RNA extraction, P19 cells were incubated at $37^{\circ} \mathrm{C}$ with (lanes $2 \& 4$ ) or without (lanes $1 \& 3$ ) retinoic acid for 4 days. RT-PCR amplification was performed as previously described. The products amplified by the Sec61 $\alpha$ primers (lanes $1 \& 2$ ) and control actin primers (3 \& 4) were run side-byside on the gels, stained with ethidium bromide, and photographed. The expected size of the amplified product of Sec61 $\alpha$ was 410 base pairs on the basis of gel electrophoresis. The expected size of the actin control was 490 base pairs.

\section{DISCUSSION}

Retinoic acid is an established regulator of epithelial cell differentiation in vivo and in vitro (DeLuca, 1992; Zou et al., 1994). One of the major physiological functions of retinoic acid is to prevent squamous differentiation (Jetten et al., 1992; Lotan, 1993; Kubota et al., 2001; Fischer et al., 2000). Squamous metaplasia, which develops during vitamin A deficiency, can be reversed by supplementation with retinoic acid (Lotan,
1993). Furthermore, retinoic acid suppresses squamous cell differentiation that either occurs spontaneously or is induced by calcium ions in cultured normal keratinocytes or tracheal cells (Jetten et al., 1992; Kubota et al., 2001). In the presence of retinoic acid and dibutyryl cAMP, F9 cells can be induced to differentiate into parietal endodermal cells (primitive endoderm-like cells) (Strickland et al., 1980; Kubota et al., 2001).

The phenotype of the new cell type is characterized by synthesis of plasminogen activator, 
laminin, and type IV collagen, and by low levels of alkaline phosphatase and lactase dehydrogenase. The cell type generated by this induction does not depend upon the continued presence of either compound, but the cAMP agents are active only on F9 cells treated with retinoic acid (Strickland \& Mahdavi, 1978; Jetten et al., 1979). This differentiation of the tumorigenic F9 stem cells results in tumorigenicity loss (Strickland et al., 1980; Kubota et al., 2001). This differentiation response of F9 cells is irreversible, fairly synchronous, and rapid (within 24 to 48 hours) (Jetten et al., 1979; Kubota et al., 2001).

The molecular mechanisms by which retinoids exert such potent effects on the growth, differentiation, and neoplastic transformation of a variety of different cell types have not been elucidated, even though many of these retinoid effects have been known for over 60 years. There is some evidence that retinoids may act in a manner similar to that of steroid hormones (Lotan, 1980; Wan et $a l ., 2001)$. Although the exact mechanism whereby $\mathrm{RA}$ regulates gene expression and differentiation is not completely understood, it is likely that highaffinity RA receptors and/or binding proteins are involved (Sato et al., 2001).

Previous study has investigated the production of Sec61 $\alpha$ and other translocon components following retinoic acid treatment in F9 teratocarcinoma cells (Ferreira et al., 2002). The production of Sec61o was shown to markedly increase following retinoic acid treatment in treated F9 cells, whereas undetected Sec61 $\alpha$ amounts were observed in untreated F9 cells. However, another translocon component, TRAM, was present in both retinoic acid-treated and control samples (Ferreira et al., 2002).

The relevance of undetectable levels of Sec61 $\alpha$ in undifferentiated F9 cells is not known. However, Sec61 $\alpha$ was essential for secretory protein translocation (Kellaris et al., 1991). The mechanism whereby these tumor cells secrete proteins without detectable $\operatorname{Sec} 61 \alpha$ amounts is still not well understood. Among mammalian species, the cDNA sequence for the $\operatorname{Sec} 61 \alpha$ gene is known for rats, dogs, and humans. However, there has also been no convincing evidence in any system that retinoic acid regulates Sec61 $\alpha$ transcription.

In this study, the cDNA samples from F9 cells amplified with Sec61 $\alpha$ primer were demonstrated in samples of cells treated with retinoic acid, but not in control cell samples. The PCR samples from P19 cells demonstrated an amplified product for Sec61 $\alpha$ primer in retinoic acid treated and untreated samples. These findings may suggest that $\operatorname{Sec} 61 \alpha$ expression depends on F9 teratocarcinoma cell differentiation into parietal endoderm cells following retinoic acid treatment. Whether the cell differentiation stage regulates Sec61 $\alpha$ expression is still not clear.

Acknowledgments - We acknowledge financial support from FAPEMIG (proc. n. CDS 2228/96) and PUC-MG, Poços de Caldas.

\section{REFERENCES}

BOYLAN, J. F. \& GUDAS, J. L., 1991, Over expression of the cellular retinoic acid binding protein-I (CRABP-I) results in reduction of differentiation-specific gene expression in $\mathrm{F} 9$ teratocarcinoma cells. J. Cell Biol., 112: 965-979.

BRIETMAN, T. R., SELONICK, S. \& COLLINS, S. J., 1980, Induction of differentiation of the human promyelocytic leukemia cell line (HL-60) by retinoic acid. Proc. Natl. Acad. Sci, USA, 77: 2936-2940.

DELUCA, L. M., 1992, Retinoids and their receptors in differentiation, embryogenesis and neoplasia. FASEB J., 5: 2924-2933.

FERREIRA, L. R., VELANO, C. E. E., BRAGA, E. C., PAULA, C. C., JUNIOR, H. M. \& SAUK, J. J., 2002, Sec61 $\alpha$ protein synthesis is enhanced during translocation of nascent chains of collagen type IV in F9 teratocarcinoma cells after retinoic acid treatment. Braz. J. Med. Biol. Res. (accepted for publication, August 19, 2002).

FERNANDEZ-RACHUBINSKI, F. \& FLIEGEL, L., 2001, COUP-TFI and COUP-TFII regulates expression of the NHE through a nuclear hormone responsive element with enhancer activity. Eur. J. Biochem. 268(3): 620-634.

FISCHER, H. S., BERTI, I., SCHATZ, D. S., HUMPEL, C. \& SARIA, A., 2000, Retinoic acid treatment enhances the acetylcholine contents in human teratocarcinoma cell line Ntera-2. Regul. Pept., 96(1-2): 59-63.

GORLICH, D., PREHN, S., HARTMAN, E., KALLIES, K. U. \& RAPOPORT, T. A., 1992, A mammalian homolog of SecYp is associated with ribosomes and nascent polypeptides during translocation. Cell, 71: 489-503.

GREENFIELD, J. J. \& HIGH, S., 1999, The sec61 complex is located in both the ER and ER-Golgi intermediate compartment. J. Cell Sci., 112: 1477-1486.

HAUSSLER, M., SIDELL, N., KELLY, M., DONALDSON, C., ALTMAN, A. \& MANGELSDORF, D., 1983, Specific highaffinity binding and biologic action of retinoic acid in human neuroblastoma cell lines. Proc. Natl. Acad. Sci, USA, 80: 5525-5529.

HONG, W. K., ENDICOTT, J., ITRI, L. M., DOOS, W., BATSAKIS, J. G., BELL, R., FOFONOFF, S., BYERS, R., ATKINSONS, E .N., VAUGHAN, C., TOTH, B. B., KRAMER, A., DIMERY, I. W., SKIPPER, P. \& STRONG, S., 1986, 1,3-cis Retinoic acid in the treatment of oral leukoplakia. N. Engl. J. Med., 315: 1501-1505. 
HUSSAIN, A. M., LEE, H. C. \& CHANG, C. F., 2000 Modulation of CD157 expression in multi-lineage myeloid differentiation of promyelocytic cell lines. Eur. J. Cell Biol., 79(10): 697-706.

JETTEN, A., JETTEN, M. \& SHERMAN, M., 1979, Stimulation of differentiation of several murine embryonal carcinoma cell lines by retinoic acid. Exp. Cell Res., 124: 381-391.

JETTEN, A. M., NERVI, C. \& VOLBERG, T. M., 1992, Control of squamous differentiation in tracheobronchial and epidermal epithelial cells: Role of retinoids. J. Natl. Cancer Inst. Monogr., 13: 93-100.

KELLARIS, K. V., BOWEN, S. \& GILMORE, R., 1991, ER translocation intermediates are adjacent to a nonglycososylated $34-\mathrm{kD}$ integral membrane protein. J. Cell Biol., 114: 21-33.

KIKUGAWA, T., TANJI, N., MIYAZAKI, T. \& YOKOYAMA, M., 2000, Immunohistochemical study of receptors for retinoic acid in prostatic adenocarcinoma. Anticancer Res., 20(5C): 3897-3902.

KRAEMER, K. H., DIGIOVANNA, J. J., MOSHELL, A. N., TARONE, R. E. \& PECK, G. L., 1988, Prevention of skin cancer in xeroderma pigmentosum with the use of oral isoretinoin. N. Engl. Med., 318: 1633-1637.

KUBOTA, H., CHIBA, H., TAKAKUWA, Y., OSANAI, M., TOBIOKA, H., KOHAMA, G., MORI, M. \& SWADA, N., 2001, Retinoic X receptor alpha and retinoic acid receptor gamma mediate expression of genes ecoding tight-junction proteins and barrier function in F9 cells during visceral endodermal differentiaton. Exp. Cell Res., 263(1): 163-172.

LAROSA, G. J. \& GUDAS, L. J., 1988, An early effect of retinoic acid: cloning of an mRNA (ERA-1) exhibiting rapid protein synthesis and independent induction during teratocarcinoma stem cell differentiation. Proc. Natl. Acad. Sci., USA, 85: 329-333

LOTAN, R., 1980, Effects of vitamin A and its analogs (retinoids) on normal and neoplastic cells. Biochim. Biophys. Acta, 605: 33-91.

LOTAN, R., 1993, Retinoids and squamous cell differentiation In: W. K. Hong \& R. Lotan (eds.), Retinoids in oncology. Marcel Decker Press, New York, NY, pp. 43-72.

LOTAN, R. \& LOTAN, D., 1980, Stimulation of melanogenesis in human melanoma cell line by retinoids. Cancer Res., 40: 3345-3350.

MOON, R. C. \& METHA, R. G., 1990, Retinoid inhibition of experimental carcinogenesis. In: M. I. Dawson \& W. H. Okamura (eds.), Chemistry and biology of synthetic retinoids. CRC Press, Boca Raton, FL, pp. 501-518.

RAPOPORT, T. A., MATLACK, K. E., PLATH, K., MISSELWITZ B. \& STAECK, O., 1999, Posttranslational protein translocation across the membrane of endoplasmic reticulum. J. Biol. Chem., 380: 1143-1150.

SATO, M., YAJIMA, Y., KAWASHIMA, S., TANAKA, K. \& KAGECHIKA, H., 2001, Synergistic potentiation of thiazolidinedione-induced ST 13 preadipocyte differentiation by RAR synergists. Biochem. Biophys Res. Commun., 280(3): 646-651.
SHKLAR, G., SCHWARTZ, J., GRAU, D., TRICKLER, D. P. \& WALLACE, K. D., 1980, Inhibition of hamster buccal pouch carcinogenesis by 1,3-cis-retinoic acid. Oral Surg., 50: 45-52.

SIMON, S. M. \& BLOBEL, G., 1991, A protein conducting channel in the endoplasmic reticulum. Cell, 65: 371-380.

SMITH, M. A., PARKINSON, D. R., CHESON, B. D. \& FRIEDMAN, M. A., 1992, Retinoids in cancer therapy. $J$. Clin. Oncol., 10: 839-864.

STRICKLAND, S. \& MAHDAVI, V., 1978, The induction of differentiation in teratocarcinoma stem cells by retinoic acid. Cell, 15: 393-403.

STRICKLAND, S., SMITH, K. K. \& MAROTTI, K. R., 1980, Hormonal induction of differentiation in teratocarcinoma cells: Generation of parietal endoderm by retinoic acid and dibutyryl cAMP. Cell, 21: 347-355.

TICKLE, C., ALBERTS, B., WOLPERT, L. \& LEE, J., 1982 Local application of retinoic acid to the limb bud mimics the action of polarizing region. Nature, 296: 564-566.

TICKLE, C., LEE, J. \& EICHELE, G., 1985, A quantitative analysis of the effect of all-trans retinoic acid on the pattern of chick wing development. Dev. Biol., 109: 82-95.

TREIGYTE, G., NAVAKAUSKIENE, R., KULYTE, A., GINETIS, A. \& MAGNUSSON, K. E., 2000, Tyrosine phosphorylation of cytoplasmic proteins in proliferating, differentiating, apoptotic HL-60 cells and blood neutrophils. Cell. Mol. Life Sci., 57(13-14): 1997-2008.

WAKABAYASHI, N., KAGEYAMA, R., HABU, T., DOI, T., MORITA, T., NOZAKI, M., YAMAMOTO, M. \& NISHIMUNE, Y., 2000, A novel-cis-acting element regulates HSE-1 gene expression in P19 embryonal carcinoma cells treated with retinoic acid. J. Biochem., 128(6): 1087-1095.

WAN, H., HONG, W. K. \& LOTAN, R., 2001, Increased retinoic acid responsiveness in lung carcinoma cells that are nonresponsive despite the presence of endogenous retinoic acid receptor (RAR) beta by expression of exogenous retinoid receptors retinoid $\mathrm{X}$ receptor alpha, RAR alpha, and RAR gamma. Cancer Res., 61(2): 556-564.

WANG, S. Y. \& GUDAS, L. J., 1990, A retinoic acid inducible mRNA from F9 teratocarcinoma cells encodes a novel protease inhibitor homologue. J. Biol. Chem., 265: 1581815822.

ZOU, C. P., CLIFFORD, J. L., XU, X. C., SACKS, P. G., CHAMBON, P., HONG, W. K. \& LOTAN, R., 1994, Modulation by retinoic acid (RA) of squamous cell differentiation, cellular RA binding proteins, and nuclear RA receptors in human head and neck squamous cell carcinoma cell lines. Cancer Res., 54: 5479-5487. 